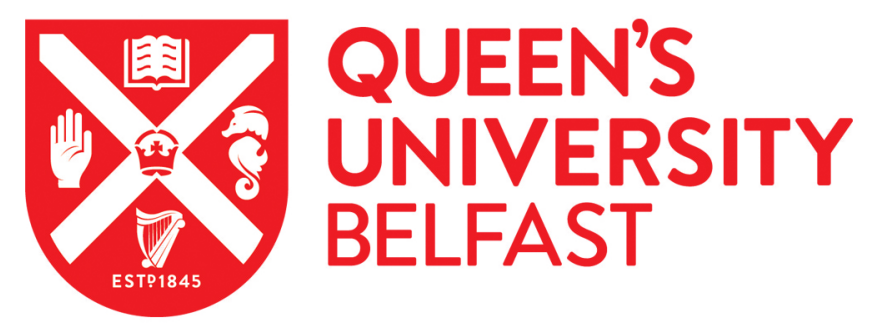

\title{
A Human Relevant Defined Mixture of Persistent Organic Pollutants (POPs) Affects In Vitro Secretion of Glucagon-Like Peptide 1 (GLP-1), but Does not Affect Translocation of its Receptor
}

Shannon, M., Xie, Y., Verhaegen, S., Wilson, J., Berntsen, H. F., Zimmer, K. E., Ropstad, E., Green, B., \& Connolly, L. (2019). A Human Relevant Defined Mixture of Persistent Organic Pollutants (POPs) Affects In Vitro Secretion of Glucagon-Like Peptide 1 (GLP-1), but Does not Affect Translocation of its Receptor. Toxicological Sciences, 172(2), 359-367. https://doi.org/10.1093/toxsci/kfz192

Published in:

Toxicological Sciences

Document Version:

Peer reviewed version

Queen's University Belfast - Research Portal:

Link to publication record in Queen's University Belfast Research Portal

\author{
Publisher rights \\ (C) The Author(s) 2019. Published by Oxford University Press on behalf of the Society of Toxicology. This work is made available online in \\ accordance with the publisher's policies. Please refer to any applicable terms of use of the publisher.
}

\section{General rights}

Copyright for the publications made accessible via the Queen's University Belfast Research Portal is retained by the author(s) and / or other copyright owners and it is a condition of accessing these publications that users recognise and abide by the legal requirements associated with these rights.

Take down policy

The Research Portal is Queen's institutional repository that provides access to Queen's research output. Every effort has been made to ensure that content in the Research Portal does not infringe any person's rights, or applicable UK laws. If you discover content in the

Research Portal that you believe breaches copyright or violates any law, please contact openaccess@qub.ac.uk. 
A Human Relevant Defined Mixture of Persistent Organic Pollutants (POPs) Affects In Vitro Secretion of Glucagon-Like Peptide 1 (GLP-1), but Does not Affect Translocation of its Receptor

Maeve Shannon ${ }^{\mathrm{a}^{*}}$, Yuling Xie ${ }^{\mathrm{a}^{*}}$, Steven Verhaegen ${ }^{\mathrm{b}}$, Jodie Wilson ${ }^{\mathrm{a}}$, Hanne Friis Berntsen ${ }^{\mathrm{b}, \mathrm{c}}$, Karin Elisabeth Zimmer ${ }^{\mathrm{d}}$, Erik Ropstad ${ }^{\mathrm{b}}$, Brian Green ${ }^{\mathrm{a}}$, Lisa Connollya**

a Institute for Global Food Security, School of Biological Sciences, Queen's University Belfast, Northern Ireland, United Kingdom

${ }^{\mathrm{b}}$ Department of Production Animal Clinical Sciences, Faculty of Veterinary Medicine, Norwegian University of Life Sciences, Postboks 369 sentrum 0102, Oslo, Norway.

${ }^{c}$ Department of Administration, Lab Animal Unit, National Institute of Occupational Health, P.O. Box 5330, Oslo, Norway.

d Department of Basic Sciences and Aquatic Medicine, Faculty of Veterinary Medicine, Norwegian University of Life Sciences, Postboks 369 sentrum 0102, Oslo, Norway.

\section{*Joint primary co-authorship}

**Corresponding author and person to whom reprint requests should be addressed:

Dr. Lisa Connolly

Institute for Global Food Security 
Queen's University Belfast

18-30 Malone Road Belfast, BT9 5BN

Phone: +44 (0)2890976668 Email: 1.connolly@qub.ac.uk

Keywords: Metabolic disruption, Gut hormones, Mixture, Enteroendocrine cell, High Content Analysis, ELISA.

\begin{abstract}
Environmental exposure to persistent organic pollutants (POPs) has been suggested as a contributing factor for the increased rate of T2D and obesity. A complex mixture of 29 POPs (Total mixture), based on human blood concentrations was used to expose a glucagon-like peptide 1 (GLP-1) secreting enteroendocrine cell line (pGIP/neo: STC-1) in vitro, for 3 and 24 h. Significant increases of GLP-1 occurred when cells were exposed to Total Mixture at x 500 blood levels. Six sub-mixtures representing chlorinated $(\mathrm{Cl})$, brominated $(\mathrm{Br})$, and perfluorinated chemicals (PFAA), and their combinations $(\mathrm{Cl}+\mathrm{Br}, \mathrm{Cl}+\mathrm{PFAA}, \mathrm{Br}+\mathrm{PFAA})$ were also tested at x 500. Secretion levels seen for these, remained lower than for the Total mixture, and the Br mixture had no effect. After $24 \mathrm{~h}$, increased secretion was seen with all mixtures at x 1 blood levels. Cytotoxicity was present for x 100 and x 500 blood levels. When tested in a GLP-1 receptor translocation assay (U2OS-GLP1R-EGFP), neither agonistic, nor antagonist effects on receptor internalisation were seen for any of the mixtures. We conclude individual classes of POP, alone or in combination, can affect GLP-1 secretion and might contribute as a molecular mechanism, linking environmental toxicants and diabetes.
\end{abstract}




\section{Introduction}

The incidence of metabolic diseases such as metabolic syndrome, obesity, and type 2 diabetes (T2D) is increasing globally. Environmental chemicals have been proposed as additional risk factors, in addition to main contributors like genetic predisposition, excess calorie intake, or lack of exercise (Jeon et al., 2015). Experimental and epidemiological evidence suggests a role for early and chronic exposure to low doses of chemical pollutants with endocrine and metabolic disrupting activity, including persistent organic pollutants (POPs) (Chevalier and Fénichel, 2015). In humans, the main exposure to POPs in nonoccupational settings occurs through ingestion (Darnerud et al., 2006; Vestergren et al., 2012). This makes the gastrointestinal tract the first organ of exposure, and thus it is conceivable that enteroendocrine $(\mathrm{EE})$ cells are a potential target for endocrine disruption.

POPs constitute a diverse group of chemicals that are resistant to environmental degradation, bioaccumulate within living organisms, and biomagnify through the food web. Due to their mixing in the environment, food web, and the long-term accumulation in fatty tissues, exposure to POPs always occurs as a mixture (WHO/UNEP, 2013).

Human and experimental evidence linking chlorinated POPs with obesity and/or T2D has been extensively reviewed (Lee et al., 2014). Associations for brominated POPs have been reported by Lim et al., (2008). Background exposure of particular brominated POPs (PBB-153 and PBDE-153) may be closely linked to disturbance of glucose and lipid metabolism in the general population (Lim et al., 2008). Perfluorinated alkylated acids (PFAAs) have been associated with disturbed lipid metabolism and shown to bind to peroxisome proliferatoractivated receptors (PPARs), which are of major importance for lipid metabolism and fat storage (Zhang et al., 2014, Fang et al., 2015)). A study by Lind et al., 2014 assessed the relationship between circulating levels of PFAAs and markers of insulin secretion and 
resistance. The results revealed that perfluorononanoic acid (PFNA) is positively correlated to prevalent diabetes.

In addition to the mechanisms outlined above, it is possible that POP exposure leads to an endocrine disrupting action on gut hormones involved in controlling satiety responses and insulin release. GLP-1 (glucagon-like peptide 1) is one such hormonal system involved and vital in maintaining glucose and weight homeostasis.

GLP-1 is a peripheral humoral factor secreted by entero-endocrine (EE) L-type cells (Lim and Brubaker, 2006). After food ingestion, early-phase secretion starts within 10-15 mins as triggered by the mechano- and chemo-sensitive afferent neurons. Direct nutrient contact with L-cells starts GLP-1 secretion within 30 mins to three hours of meal intake. Exocytosis of GLP-1 secretory granules requires activation of intracellular signalling pathways such as PKA, PKC, and ion channels-dependent membrane depolarisation (Nadkarni, Chepurny, and Holz, 2014). Secreted GLP-1 either acts locally in the gut with EE cells, vagal afferents, or is drained into the circulation via the hepatic portal vein or lymph to bind to specific receptors (Steinert and Begliger, 2011).

The GLP-1 receptor (GLP-1 R), a class B G protein-coupled receptor (GPCR), is distributed in multiple tissues and has been known to mediate GLP-1 actions (Graaf et al., 2016). The pancreas is one of the major sites for GLP-1R expression. GLP-1 binding promotes the exocytosis of insulin vesicles in beta cells and supress the secretion of hyperglycaemic hormone glucagon in alpha cells. In addition, GLP-1 increases cell proliferation, and inhibits beta cell apoptosis.

In this study, we investigated the potential for POP mixtures to modify GLP-1 secretion, and to interact with the GLP-1R, providing insight into alternative mechanisms by which POPs may be involved in the pathogenesis of diabetes and obesity. 
In addition, to simulate real-life exposure scenarios relevant to humans, we utilised a synthetic mixture of 29 different POPs (Table 1) designed as relevant to the Scandinavian population, with the individual concentration of the different POPs based on mean human blood levels (Supplementary table 3). In addition to the Total mixture, 6 sub-mixtures containing the same concentration of chlorinated + brominated $(\mathrm{Cl}+\mathrm{Br})$, chlorinated + perfluorinated $(\mathrm{Cl}+$ PFAA $)$, brominated + perfluorinated $(\mathrm{Br}+$ PFAA $)$, or chlorinated $(\mathrm{Cl})$, brominated (Br) or perfluorinated compounds (PFAA) only were constructed. Using these submixtures enables investigating the effect of adding or removing one or more chemical groups (Berntsen et al., 2017). The concentration of the 29 POPs within the mixtures were based on the blood levels found in the Scandinavian population. However, a wider range of concentrations (from below and up to 500x blood levels) were tested to reflect human body burden levels in different exposure scenarios, including populations exposed to much higher POP concentrations. For example, Chinese occupational exposure to PFAAs is 100 to 500 times higher than that reported in the Scandinavian population (Fu et al., 20166). In addition, the US exposure levels to some POPs are ten to hundreds of times higher than the European population (Schecter et al., 2005). The body burden of POPs is higher also in Inuit populations (Krüger et al., 2007; Laird, Goncharov and Chan, 2013).

In summary, this study investigates seven complex POP mixtures relevant to real life human exposure scenarios (Berntsen et al., 2017) for effects on:

1. Cytotoxicity on GLP-1 secreting EE gut cells (pGIP/neo: a sub-clone of the STC-1 cell line).

2. GLP-1 hormone secretion by EE gut cells.

3. Endocrine disrupting potential via (ant)agonism of the GLP-1 receptor internalization in the U2OS-GLP1R-EGFP cell line. 


\section{Material and Methods}

\subsection{Chemicals}

All brominated and chlorinated chemicals were originally purchased from Chiron As (Trondheim, Norway). All PFAAs were obtained from Sigma-Aldrich (St. Louis, MO, USA) except perfluorohexanesulfonic acid (PFHxS) which was from Santa Cruz (Dallas, US). Hexabromocyclododecane (HBCD) was obtained from Sigma-Aldrich (Dorset, UK). Mitochondrial membrane potential dye (MMPD) and Hoechst nuclear stain 33342 were purchased from Perbio (Northumberland, England)). Cell culture reagents were supplied by Life Technologies (Paisley, UK). All other reagents were standard laboratory grade.

\subsection{Mixtures of Persistent Organic Pollutants (POPs)}

The POP mixtures used in the study were based on concentrations of relevant POPs measured in human blood of Scandinavian population. The compounds were mixed in concentration ratios relevant to average human blood levels. An extensive description and information of chemical composition and concentrations can be found in Berntsen et al., 2017. Seven mixtures were used in the study: (1) Total mixture, containing all the test compounds, (2) chlorinated mixture $(\mathrm{Cl}),(3)$ brominated mixture $(\mathrm{Br}),(4)$ perfluorinated mixture (PFAA), (5) chlorinated and brominated mixture $(\mathrm{Cl}+\mathrm{Br})$, (6) chlorinated and perfluorinated mixture $(\mathrm{Cl}+\mathrm{PFAA})$ and $(7)$ brominated and perfluorinated mixture $(\mathrm{Br}+\mathrm{PFAA})$.

\subsection{Cell culture}


pGIP/neo: STC-1 cells are an EE cell model and its GLP-1 secretory ability has been extensively investigated (Gillespie et al., 2015; Hand et al., 2012; Jafri et al., 2016). These were a gift from Dr. B. Wice (Washington University of St. Louis) with permission from Dr. D. Hanahan (University of California, San Francisco, CA). Cells were cultured in DMEM with Glutamax, 10\% FBS, 1\% penicillin and streptomycin, and $50 \mathrm{mg} / \mathrm{ml} \mathrm{G} 418$. Cells were used between passages $15-50$.

The U2OS-GLP1R-EGFP cell line is obtained from Thermo Scientific (UK), which stably express the human GLP-1R with a C-terminal enhanced green fluorescent protein tag. The cells were cultured routinely in Dulbecco's Modified Eagle Medium (DMEM) with Glutamax, 10\% foetal bovine serum (FBS), 1\% penicillin and streptomycin, and $50 \mathrm{mg} / \mathrm{ml}$ G418 at $37^{\circ} \mathrm{C}$ with $5 \% \mathrm{CO} 2$. The assay has been validated with cells up to a passage of 30 (Thermo Scientific, UK).

\subsection{Analysis of cytotoxicity parameters by High Content Analysis (HCA)}

Briefly, pGIP/neo: STC-1 cells were seeded $6 \times 10^{4}$ in 96 -well plates $24 \mathrm{~h}$ prior to the assay. MMPD was prepared by adding $117 \mu \mathrm{l}$ of anhydrous DMSO to make a $1 \mathrm{mM}$ stock. Following incubation ( $3 \mathrm{~h}$ and $24 \mathrm{~h}$ ), $50 \mu \mathrm{l}$ of live cell stain was added to each well for $30 \mathrm{~min}$ at $37^{\circ} \mathrm{C}$ and protected from light. The live stain was removed and cells were then fixed with a $10 \%$ formalin solution for 20 min at RT, and washed with PBS. Hoechst 33342 dye at a final concentration of $1.6 \mu \mathrm{M}$ was added to each well and incubated for $10 \mathrm{~min}$ at RT; after which cells were washed with PBS four times and evaluated on a CellInsightTM NXT High Content Screening (HCS) Platform (Thermo Fisher Scientific, UK). Data were captured at X20 objective magnification with selected filters: Hoechst dye (Ex/Em 350/461 nm) and MMPD $(\mathrm{Ex} / \mathrm{Em} 554 / 576 \mathrm{~nm})$.

\subsection{GLP-1 secretion studies}


The pGIP/neo: STC-1 cells were seeded into 24 -well plates $\left(1 \times 10^{6}\right.$ per well $)$ and cultured overnight at $37{ }^{\circ} \mathrm{C}$ in a humidified atmosphere of $5 \% \mathrm{CO}_{2}$. Medium was removed and cells were washed once with HBSS buffer and equilibrated for $1 \mathrm{~h}$ in $500 \mu \mathrm{HBSS}$ buffer. Forskolin and IBMX were used as a combined positive control at a concentration of $10 \mu \mathrm{M}$ each. POP mixtures, positive control, and solvent control were made at a final dimethyl sulfoxide (DMSO) concentration of $0.2 \%$ in HBSS buffer. One $\mathrm{ml}$ of each working concentration of POP mixtures containing HBSS buffer, or $500 \mu 1$ of DMSO solvent control, was added to the relevant wells of the plate. For $24 \mathrm{~h}$ study, POP mixtures and controls were added in serum containing DMEM. Supernatant was removed after 3 and 24 h and stored at $20^{\circ} \mathrm{C}$ prior to GLP-1 ELISA analysis.

\subsection{Hormone analysis}

GLP-1 was measured using a Glucagon Like Peptide-1 (GLP-1) (Active) ELISA kit (EGLP-35K; in accordance with the manufacturer's instructions (Millipore, Watford, UK)). All experiments were performed in triplicate for each experimental point and repeated in three independent experiments. For $3 \mathrm{~h}$ exposure, the supernatants were diluted by HBSS buffer 1 in 4 prior to the measurement of GLP-1 hormone levels by ELISA. For $24 \mathrm{~h}$ exposure, the supernatants were diluted by 1 in 40 in media. Absorbance was measured using a Sunrise spectrophotometer (TECAN, Switzerland).

\subsection{GLP-1 redistribution assay}

U2OS-GLP1R-EGFP cells were seeded (100 $\mu 1$ of 6 x $10^{4}$ cells/well) in 96-well black plates with clear, flat bottoms in seeding media (DMEM with Glutamax, 1\% FBS, 1\% penicillin and streptomycin $(50 \mathrm{U} / \mathrm{ml}))$. After $24 \mathrm{~h}, 100 \mu \mathrm{l}$ of the POP mixtures and the GLP-1 (7-37) standards at a final DMSO concentration of $0.2 \%$ were added into plates. Test mixtures and standards were diluted in serum free media. The ability of $150 \mathrm{nM}$ GLP-1 to induce 
internalisation of the receptor was assessed in the presence and absence of the mixtures. Cells were incubated for $1 \mathrm{~h}$ then fixed with formalin (approximately $4 \%$ formaldehyde) for $20 \mathrm{~min}$. Cells were washed, then followed by addition of $100 \mu \mathrm{l}$ of $1 \mu \mathrm{M}$ Hoechst staining solution. After 30 min, the plate was imaged on a HCS Platform with the filters: Hoechst dye (350/461 nm) and GFP/FITC (488/509 nm) (Thermo Fisher Scientific, UK). The assay was performed in triplicate for each experimental point and repeated in three independent exposures.

\subsection{Statistical analysis}

All values shown are expressed as mean \pm standard error of the mean (SEM) of the three independent exposures for the POP mixtures. Data from the HCA cytotoxicity, GLP-1 secretion and GLP-1R redistribution assays were analysed using Microsoft Excel and GraphPad PRISM 5 software (GraphPad Software Inc, San Diego, CA). A one-way analysis of variance (ANOVA) followed by Dunnett's multiple comparison test was used to determine significant differences between treatments and the corresponding control. A $P$-value of $\leq 0.05$ was considered as significant $(P \leq 0.05 *, P \leq 0.01 * *$ and $P \leq 0.001 * * *)$.

\section{Results}

3.1. Effects of POP mixture exposure on Cellular Health and GLP-1 secretion in $\mathrm{pGIP/neo:}$ STC-1 cells

\subsubsection{Cellular Health evaluated by HCA analysis}

The general health of the exposed cell populations was evaluated by a multi-parameter approach on an HCA platform. Hoechst-staining of nuclei provided information on cell number (object count) and possible morphological changes were monitored using nuclear area (NA) 
and nuclear intensity (NI). A mitochondrial specific fluorescent label was used to quantitate mitochondrial mass (MM) and the mitochondrial membrane potential (MMP). Mean values, standard error of mean, and p-values for total mixture and the 6 sub-mixtures are listed in Supplementary Table 1 (Shannon et al., 2019).

In summary, exposure to the Total mixture (1:10 to x 500 blood level) for $3 \mathrm{~h}$ did not significantly alter the cell number. For $24 \mathrm{~h}$ exposure, a reduction in cell number compared to solvent control ( $0.2 \%$ DMSO) was seen for the two highest concentrations tested (x 100 and $\mathrm{x}$ 500) (Fig.1A). No significant changes were seen for the $\mathrm{Cl}$ mixture after $3 \mathrm{~h}$ exposure (Fig 1A), however after $24 \mathrm{~h}$, all concentrations tested led to a significant reduction (Fig. 1B). For the $\mathrm{Br}$ mixture at $3 \mathrm{~h}$ exposure only x 500 led to a significant decrease (Fig.1A), whilst for $24 \mathrm{~h}$ significant decreases were seen for x 50 and higher (Fig. 1B). PFAA exposure had no effect at $3 \mathrm{~h}$, but reduced cell number from x 1 blood level onwards after $24 \mathrm{~h}$ (Fig. 1B). $\mathrm{Cl}+\mathrm{Br}$ mixture did not induce any significant decrease after $3 \mathrm{~h}$ exposure, while $24 \mathrm{~h}$ treatment resulted in the significant decrease for x 50, x 100, and x 500 blood level (Fig. 1B). For the PFAA $+\mathrm{Cl}$ mixture, a significant decrease in cell number was seen for x 100 and x 500 after $3 \mathrm{~h}$ exposure (Fig. 1A). For 24h, a decrease was already seen form x 50 onwards (Fig. 1B). Br +PFAAs mixture exposure at $3 \mathrm{~h}$ only caused significant decrease at x 500 blood level (Fig. 1A), however, the $24 \mathrm{~h}$ exposure induced significant decrease at all tested concentrations (Fig. 1B).

Apart from cell number, cellular health was further evaluated using the area and fluorescent intensity of selected nuclei as pre-lethal markers. Only the $\mathrm{Br}, \mathrm{PFAA}$, and $\mathrm{Br}+$ PFAA mixtures induced significant nuclear area decrease at x 500 after 24 h exposure (Fig. 2). Other mixtures did not change nuclear area significantly at all tested levels for 3 or $24 \mathrm{~h}$ (Supp. Table 1A and B). Exposure to any of the seven mixtures tested did not induce any significant change of nuclear intensity (Supp. Table 1A and B). 
Finally, markers for mitochondrial health, mitochondrial mass (MM) and mitochondrial membrane potential (MMP) were evaluated. For MM no significant changes were observed for any of the seven mixtures at the five concentrations tested. A summary of the results is shown in Supplementary Table 1A (3 h exposure) and 1B (24 h exposure) (Shannon et al., 2019). Cytotoxicity results in fewer cells and a reduction in MMP. The uptake of MMPD is dependent on MMP levels. Therefore, lower MMP levels is reflected in a decrease of MMPD intensity as quantified by HCA measurement. Such changes are illustrated in Fig.3 whereby the PFAAs + Br mix at 500 times blood levels induced nuclear and mitochondrial changes as shown by a decrease in cell number and decrease in fluorescence intensity when compared to the DMSO solvent control. Visual changes in decreased MMPD dye intensity corresponding to MMP levels after $24 \mathrm{~h}$ exposure to the POP mixtures is illustrated in Fig 4.

\subsubsection{GLP-1 secretion by pGIP/neo: STC-1 cells by ELISA analysis of Culture Medium}

Exposure of the $\mathrm{pGIP/neo:} \mathrm{STC-1} \mathrm{cells} \mathrm{were} \mathrm{limited} \mathrm{to} \mathrm{non-cytotoxic} \mathrm{ranges.} \mathrm{Thus,} \mathrm{for}$ $3 \mathrm{~h}$ exposure, concentrations of the POP mixtures tested ranged from 1:10 to x 500 blood level. For $24 \mathrm{~h}$ exposure, the concentration range was limited from 1:10 to x 50. Basal levels of GLP-1 were measured in cells exposed to $0.2 \%$ DMSO only (Solvent Control - SC). Forskolin combined with 3-isobutyl-1-methylxanthine (IBMX) was used as positive control (PC) that trigger GLP-1 secretion via cAMP-elevating and intracellular calcium pathways (Simpson et al., 2007). The collected media were analysed by ELISA to quantify active GLP-1. Mean values, standard error of mean, and p-values for all mixtures tested, at all concentrations are summarized in Suppl. Table 2 for $3 \mathrm{hr}$ exposure (2A) and $24 \mathrm{hr}$ (2B) (Shannon et al., 2019).

Total mixture increased the GLP-1 secretion significantly at x 500 blood levels after 3 $\mathrm{h}$ exposure (Fig 5A); while the secretion enhanced significantly at all tested levels $(1: 10, \mathrm{x} 1$, and x 50 blood level) after $24 \mathrm{~h}$ exposure (Fig. 5B). For $\mathrm{Cl}$ mixture, $3 \mathrm{~h}$ exposure significant 
increased GLP-1 secretion at all concentrations tested (Fig 5B); however, 24 h exposure only promoted secretion at $\mathrm{x} 1$ and $\mathrm{x} 50$ blood level (Fig 6). The Br mixture failed to induce any significant change in GLP-1 secretion compared to the solvent control at $3 \mathrm{~h}$ (Fig 5B), while the significant increase GLP-1 levels detected after $24 \mathrm{~h}$ exposure at x 1 and x 50 blood level (Fig. 6). The PFAAs mixture led to significant GLP-1 level increase at the highest concentration after $3 \mathrm{~h}$ (Fig 5B), and the pro-longed exposure resulted in the significant increase at $\mathrm{x} 1$ and $\mathrm{x} 50$ blood level (Fig. 6). The $\mathrm{Cl}+\mathrm{Br}$ and $\mathrm{Cl}+$ PFAAs mixtures induced significant GLP-1 increase at x 500 blood level after $3 \mathrm{~h}$ exposure (Fig 5B), and at all tested concentrations after $24 \mathrm{~h}$ exposure (Fig 6). For the Br + PFAAs mixture, both 3 and $24 \mathrm{~h}$ exposure resulted in significant increase at two highest tested concentrations (Fig 5B and Fig. $6)$.

3.2 Effect of POP mixture exposure on GLP-1 receptor redistribution in U2OS cells using $H C A$.

A standard curve was generated using a concentration range of GLP-1 (1-300 nM) to drive receptor internalisation. The HCA images showed the location of fluorescent GLP-1 receptor after one hour treatment of solvent control and GLP-1 (at $300 \mathrm{nM}$ ) (Supplementary Fig 1). The $\mathrm{EC}_{50}$ value was calculated as $37 \mathrm{nM}$ GLP-1. The seven POP mixtures at all concentrations tested did not change internalisation of the GLP-1R in U2OS-GLP1R-EGFP cells with or without presence of GLP-1 (Supplementary Fig 2).

\section{Discussion}

Associations between POP exposure and obesity/diabetes risk have recently been highlighted without the underlying mechanisms being identified (Evangelou et al., 2016; 
Dirinck et al., 2011; Lee et al., 2014;. Lee et al., 2017a: Lee et al., 2017b). The present study investigated the ability of human relevant POP mixtures (Berntsen et al., 2017), to potentially exert their obesogenic/diabetogenic effects via disruption to gut EE cells survival, GLP-1 secretion, and GLP-1 receptor signalling which are involved in weight and glucose homeostasis.

GLP-1 secretion from pGIP/neo STC-1 cells was determined by ELISA Five out of seven POP mixtures induced an increased GLP-1 secretion from the pGIP/neo STC-1 cells following $3 \mathrm{~h}$ exposure at higher concentrations (x 100 to x 500 blood levels) while all mixtures promoted GLP-1 secretion in the $24 \mathrm{~h}$ study at $\mathrm{x} 1: 10$ to $\mathrm{x} 50$. At this time point, higher concentrations (x 100 and x 500 blood levels) induced significant cytotoxicity thus were not tested here.

Interestingly, at $3 \mathrm{~h}$ the Total mixture induced a two times higher level of measured GLP-1, than any of its sub-mixtures tested individually. The secretion level is also higher than the summed levels seen for the $\mathrm{Cl}, \mathrm{Br}$, and PFAA mixture suggestive of additive or synergistic interactions. But as summarized in Table 2A, interactions between two chemical groups are complex, with binary mixtures stimulating GLP-1 extend to a lesser degree than would be expected by summing the two constituent mixtures.

Thus, the magnitude of GLP-1 induction by the different mixture can be ranked as follows: Total mixture $>\mathrm{Cl}+\mathrm{PFAA}>\mathrm{Br}+\mathrm{PFAA}>\mathrm{PFAA}>\mathrm{Cl}>\mathrm{Cl}+\mathrm{Br}>\mathrm{Br}$.

The $24 \mathrm{~h}$ exposure induced considerable GLP-1 secretion even at concentration as low as x1 1:10 blood levels, at x 50 blood levels the Total mixture still did not plateau out GLP-1 secretion as exposure of forskolin $(10 \mu \mathrm{M})$, combined with IBMX $(10 \mu \mathrm{M})$ still induced greater GLP-1 secretion. Secretion of GLP-1 peptide from pGIP/neo STC-1 is triggered by several cellular pathways including cAMP/ PKA, PKC, and intracellular calcium ion levels (Hand, 
Giblin, and Green, 2012). $\gamma-\mathrm{HCH}$, PFOA, PFOS, and selective PCB congeners increased the levels of intracellular calcium in previous studies (Harada et al., 2005; Liu et al., 2011; Pessah et al., 2006; Silvestroni et al.,1997; Westerink, 2013). Only PBDE-47 increased the intracellular calcium levels at both 2 and $20 \mu \mathrm{M}$, but other more highly brominated congeners did not induce significant calcium fluctuation (Dingemans et al., 2009; Dingemans et al., 2016). The different effects on GLP-1 secretion between the POP mixtures may be due to their various potential effects on intracellular Ca ion levels.

Taylor et al., 2013 reviewed epidemiological studies of POPs exposure and diabetes and pointed out organochloride chemicals exposure were positively related to T2D, with nonorganochlorine POPs such as perfluoroalkyl acids and brominated compounds showed less association. Our observations indicate however that perfluorinated, as well as brominated POPs should be evaluated in mechanistic assays related to T2D, as it is clear they might have significant contribution to the effect, or affect outcome through combinatorial effects.

HCA provides the means to investigate the cellular health of $\mathrm{pGIP} /$ neo STC-1 cells at the level of pre-lethal cytotoxicity, whereby cells may still be alive but becoming unhealthy and jeopardising the ability to function optimally (Clarke et al., 2015; Wilson et al., 2016). It has been proposed that both cell number and nuclear area are among the most sensitive indicators of changes in cellular health (O'Brien et al., 2006). The Total mixture only induced a decrease of cell number at the higher concentrations after $24 \mathrm{~h}$ exposure. Individual mixtures and sub-mixtures induced more remarkable changes (Fig 4). Cl mixtures decreased cell number after $24 \mathrm{~h}$ exposure at lower concentrations. Br induced MMP decrease and nuclear area decrease for both 3 and $24 \mathrm{~h}$ exposure. The $3 \mathrm{~h}$ exposure to the PFAAs mixture resulted in a significant reduction of cell number and effects on MMP at the higher concentrations. More profound toxic effects at lower concentrations were observed among these four mixtures following $24 \mathrm{~h}$ exposure. However, the $\mathrm{Cl}+\mathrm{Br}$ mixture only led to a reduction of cell number 
for $24 \mathrm{~h}$ at high concentrations, which suggests that the $\mathrm{Cl}$ compounds might compensate for the $\mathrm{Br}$ compounds induced cellular damage. $\mathrm{Cl}+$ PFAA mixture led to cell number reduction after $3 \mathrm{~h}$, but did not show in $\mathrm{Cl}$ or PFAA mixtures, which indicates the additive effect when $\mathrm{Cl}$ and PFAA chemicals mixed together. However, the additive effect was not observed for 24 h exposure. $\mathrm{Br}+\mathrm{PFAA}$ mixture led to MMP decrease at lower concentrations than individual $\mathrm{Br}$ or PFAA mixtures. Thus, the $\mathrm{Br}$ and PFAA compounds might lead to the additive effect on the cellular damage via mitochondrial impairment. In summary, reduction of the cell number can be ranked as: $\mathrm{Br}>\mathrm{Br}+\mathrm{PFAA}>\mathrm{Cl}+\mathrm{PFAA}>\mathrm{Cl}+\mathrm{Br}>\mathrm{Cl}>\mathrm{PFAA}>$ Total mixture.

The decrease in MMP along with the decrease in cell number is indicative of mitochondrial dysfunction, and in some case this is considered as an early marker for cell death pathways (Bernardi et al., 1992; Gottlieb et al., 2003). In some cases, a decrease in cell number was observed without changes in nuclear and mitochondrial parameters. This reduction is often the first consequence of toxic impact, even before cytotoxic parameters appear within the cell, therefore making it one of the most sensitive markers of cell health (Lucke and Mumtsidu, 2010). Abnormal mitochondrial function has been associated with diseases such as diabetes and metabolic syndrome in epidemiological studies, highlighting the significance of the results found in the present study in relation to mitochondrial effects (Park et al., 2013). The $\mathrm{Br}$ mixture presented higher cytotoxicity that the other POP mixtures and induced a decrease in secretion of GLP-1 by the gip/neo STC-1 gut cells. In contrast, the Total mixture induced the greatest increase by the mixtures on GLP-1 secretion in the gip/neo STC-1 gut cells. Thus, gut cells cytotoxicity may reduce function and secretion on GLP-1. On the other hand, the toxic impact may result in an altered gut microbiome which has been linked to increased obesity risk (Riva et al., 2017).

No receptor translocation was observed in U2OS-GLP1R-EGFP cells after exposure to any mixtures at tested concentrations. The receptor redistribution in vitro assay was validated 
and applied in previous study (Shannon et al., 2017). This is the first study to investigate the interaction of POPs with GLP-1 receptor signalling. Thus, the potential activity of POPs on GLP-1 receptor signalling is difficult to predict.

\section{Conclusions}

To our knowledge, this is the first study to show that different classes of persistent organic pollutants can affect GLP-1 secretion. Interestingly, both 'legacy' POPs such as chlorinated and brominated, chemicals, as well as the emerging perfluorinated chemicals, were found to be active inducers of GLP-1 secretion. Moreover, complex mixtures combining these three groups showed combinatorial effects. Strikingly, this effect was seen with concentrations of the chemicals at levels to those observed in human blood. No effect at the level of GLP-1 receptor signalling were observed. These findings suggested POP exposure roles may contribute to the increasing rates of the pathogenesis of T2D and obesity. This study provides useful insight into the observations that POPs alter glucose homeostasis and should help guide future studies in this area.

\section{Acknowledgments}

We gratefully acknowledge PhD Studentship funding provided by the Department of Education and Learning (DEL) Northern Ireland. The POP mixtures used in this study were constructed under projects funded by the Norwegian Research Council (NFR), project 213076/H10 and project 204361/H10.

\section{References}


Alberts B., Johnson A., Lewis J., Raff M., Roberts K., and Watter P. (2002). Molecular Biology of the Cell. 4th edition. New York: Garland Science; The Mitochondrion. Available from: https://www.ncbi.nlm.nih.gov/books/NBK26894/

Baggio L. and Drucker D. (2007). Biology of Incretins: GLP-1 and GIP. Gastroenterology, $132,2131-2157$.

Bernardi P., Vassanelli S., Veronese P., Colonna R., and Szabo I. (1992). Modulation of the Mitochondrial Permeability Transition Pore. The Journal of Biological Chemistry, 267(5), 2934-2939.

Berntsen H.F., Berg V., Thomsen C., Lyche J.L., Ropstad E., Zimmer K.E. (2017). The design of an environmentally relevant mixture of persistent organic pollutants for use in in vivo and in vitro studies. Journal of Toxicology and Environmental Health 80, 16-18.

Berntsen H., Bjørklund C., Audinot J., Hofer T., Verhaegen S., Lentzen E., Gutleb A. and Ropstad, E. (2017). Time-dependent effects of perfluorinated compounds on viability in cerebellar granule neurons: Dependence on carbon chain length and functional group attached. Neurotoxicology 63, 70-83

Chevalier N., and Fénichel P. (2015). Endocrine disruptors: New players in the pathophysiology of type 2 diabetes? Diabetes and Metabolism, 41(2), 107-115.

Clarke R., Connolly L., Frizzell C., and Elliott C. T. (2015). High content analysis: A sensitive tool to detect and quantify the cytotoxic, synergistic and antagonistic effects of chemical contaminants in foods. Toxicology Letters, 233(3), 278-286.

Darnerud PO., Atuma S., Aune M., Bjerselius R., Glynn A., Grawé K. P., Becker W. (2006). Dietary intake estimations of organohalogen contaminants (dioxins, PCB, PBDE 
and chlorinated pesticides, e.g. DDT) based on Swedish market basket data. Food Chem Toxicol, 44, 1597-1606.

Dirinck E., Jorens P. G., Covaci A., Geens T., Roosens L., Neels H., and Van Gaal L. (2011). Obesity and Persistent Organic Pollutants: Possible Obesogenic Effect of Organochlorine Pesticides and Polychlorinated Biphenyls. Obesity, 19(4), 709-714.

Dingemans, M., Heusinkveld, H., Bergman, Å., van den Berg, M. and Westerink, R. (2009). Bromination Pattern of Hydroxylated Metabolites of BDE-47 Affects Their Potency to Release Calcium from Intracellular Stores in PC12 Cells. Environmental Health Perspectives, 118(4), pp.519-525.

Dingemans, M., Kock, M. and van den Berg, M. (2016). Mechanisms of Action Point Towards Combined PBDE/NDL-PCB Risk Assessment. Toxicological Sciences, 153(2), pp.215-224.

Fu, J., Gao, Y., Cui, L., Wang, T., Liang, Y., Qu, G., Yuan, B., Wang, Y., Zhang, A. and Jiang, G. (2016). Occurrence, temporal trends, and half-lives of perfluoroalkyl acids (PFAAs) in occupational workers in China. Scientific Reports, 6(1).

Evangelou E., Ntritsos G., Chondrogiorgi M., Kavvoura F. K., Hernández A. F., Ntzani E. E., and Tzoulaki I. (2016). Exposure to pesticides and diabetes: A systematic review and meta-analysis. Environment International 91, 60-68.

Fang X., Gao G., Zhang X., and Wang H. (2015). Perfluorononanoic acid disturbed the metabolism of lipid in the liver of streptozotocin-induced diabetic rats. Toxicology Mechanisms and Methods 25(8), 622-627. 
Gillespie A. L., Calderwood D., Hobson L., and Green B. D. (2015). Whey proteins have beneficial effects on intestinal enteroendocrine cells stimulating cell growth and increasing the production and secretion of incretin hormones. Food Chemistry, 189, 120-128.

Graaf C. d., Donnelly D., Wootten D., Lau J., Sexton P. M., Miller L. J., Ahn J. M., Liao J., Fletcher M. M., Yang D., Brown A. J., Zhou C., Deng J. and Wang, M. W. (2016). Glucagon-Like Peptide-1 and Its Class B G Protein-Coupled Receptors: A Long March to Therapeutic Successes. Pharmacological reviews, 68(4), 954-1013.

Gottlieb E., Armour S. M., Harris M. H., and Thompson C. B. (2003). Mitochondrial membrane potential regulates matrix configuration and cytochrome-c release during apoptosis. Cell Death and Differentiation, 10, 709-717.

Hand K. V., Giblin L., and Green B. D. (2012). Hormone profiling in a novel enteroendocrine cell line pGIP/neo: STC-1. Metabolism: Clinical and Experimental, 61(12), 1683-6.

Harada, K., Xu, F., Ono, K., Iijima, T. and Koizumi, A. (2005). Effects of PFOS and PFOA on L-type Ca2+ currents in guinea-pig ventricular myocytes. Biochemical and Biophysical Research Communications, 329(2), pp.487-494.

Hölscher C., (2010). The Role of GLP-1 in Neuronal Activity and Neurodegeneration. Vitamins and Hormones 84, 331-354.

Jafri L., Saleem S., Calderwood D., Gillespie A., Mirza B., and Green B. D. (2016). Naturally-occurring TGR5 agonists modulating glucagon-like peptide-1 biosynthesis and secretion. Peptides 78, 51-58. 
Jeon J., Ha K., and Kim D. (2015). New risk factors for obesity and diabetes: Environmental chemicals. Journal of Diabetes Investigation 6(2), 109-111.

Krüger, T., Hjelmborg, P., Jönsson, B., Hagmar, L., Giwercman, A., Manicardi, G., Bizzaro, D., Spanò, M., Rignell-Hydbom, A., Pedersen, H., Toft, G., Bonde, J. and Bonefeld-Jørgensen, E. (2007). Xenoandrogenic Activity in Serum Differs across European and Inuit Populations. Environmental Health Perspectives, 115(Suppl 1), pp.2127.

Laird, B., Goncharov, A. and Chan, H. (2013). Body burden of metals and persistent organic pollutants among Inuit in the Canadian Arctic. Environment International, 59, pp.33-40.

Lee D. H., Lee I. K., Jin S. H., Steffes M., and Jacobs D. R. (2007). Association Between Serum Concentrations of Persistent Organic Pollutants and Insulin Resistance Among Nondiabetic Adults: Results from the National Health and Nutrition Examination Survey 1999-2002. Diabetes Care 30(3), 622-628.

Lee D., Porta M., and Vandenberg L. N. (2014). Chlorinated Persistent Organic Pollutants, Obesity, and Type 2 Diabetes. Endocrine Review 35(4), 557-601.

Lee Y.-M., Kim K.-S., Jacobs D. R., and Lee D.-H. (2017a). Persistent organic pollutants in adipose tissue should be considered in obesity research. Obesity Reviews 18, 129-139.

Lee Y., Ha C., Kim S., and Thoudam T. (2017b). Persistent organic pollutants impair insulin secretory function of pancreatic beta-cells: Human and in vitro evidence. Diabetes 66(9), 1-58.

Legler, J., Fletcher, T., Govarts, E., Porta, M., Blumberg, B., Heindel, J. J., and Trasande, L. (2015). Obesity, diabetes, and associated costs of exposure to endocrine-disrupting 
chemicals in the European Union. Journal of Clinical Endocrinology and Metabolism, 100(4), 1278-1288.

Lim G. E. and Brubaker P. L. (2006). Glucagon-Like Peptide 1 Secretion by the L-Cell, Diabetes 55, S70-S77.

Lim J., Lee D., and Jacobs D. (2008). Association of Brominated Flame Retardants With Diabetes and Metabolic Syndrome in the U.S. Population, 2003-2004. Epidemiology/Health Services Research 31(9), 1802-1807.

Lind L., Zethelius B., Salihovic S., van Bavel B., and Lind P. M. (2014). Circulating levels of perfluoroalkyl substances and prevalent diabetes in the elderly. Diabetologia, 57, 473479.

Liu, X., Jin, Y., Liu, W., Wang, F. and Hao, S. (2011). Possible mechanism of perfluorooctane sulfonate and perfluorooctanoate on the release of calcium ion from calcium stores in primary cultures of rat hippocampal neurons. Toxicology in Vitro, 25(7), pp.1294-1301.

Lucke J., and Mumtsidu E. (2010) Evaluation of Compound Cytotoxicity using the Opera. Mitochondrial Mass, Cell Count, Membrane Permeability and Nuclear Size. Available from: $\quad$ http://www.perkinelmer.co.uk/PDFs/downloads/APP-Evaluation-Compound-

\section{Cytotoxicity.pdf.}

Murphy K.G, and Bloom S.R. (2006). Gut hormones and the regulation of energy homeostasis, Nature 444(7121), 854-859.

Nadkarni P., Chepurny O. G., and Holz G. G. (2014). Regulation of glucose homeostasis by GLP-1. Progress in molecular biology and translational science, 121, 23-65. 
O’Brien P. J., Irwin W., Diaz D., Howard-Cofield E., Krejsa C. M., Slaughter M. R., and Hougham C. (2006). High concordance of drug-induced human hepatotoxicity with in vitro cytotoxicity measured in a novel cell-based model using high content screening. Archives of Toxicology 80(9), 580-604.

Park W., and Jeong J. H. (2013). Novel cell-based assay reveals associations of circulating serum AhR-Ligands with metabolic syndrome and mitochondrial dysfunction. BioFactors $39(4), 494-504$.

Pessah, I., Hansen, L., Albertson, T., Garner, C., Ta, T., Do, Z., Kim, K. and Wong, P. (2006). Structure-Activity Relationship for Noncoplanar Polychlorinated Biphenyl Congeners toward the Ryanodine Receptor-Ca2+Channel Complex Type 1 (RyR1). Chemical Research in Toxicology, 19(1), pp.92-101.

Riva A., Borgo F., Lassandro C., Verduci E., Morace G., Borghi E., and Berry D. (2017). Pediatric obesity is associated with an altered gut microbiota and discordant shifts in Firmicutes populations. Environmental Microbiology 19(1), 95-105.

Schecter, A., Päpke, O., Tung, K., Joseph, J., Harris, T. and Dahlgren, J. (2005). Polybrominated Diphenyl Ether Flame Retardants in the U.S. Population: Current Levels, Temporal Trends, and Comparison With Dioxins, Dibenzofurans, and Polychlorinated Biphenyls. Journal of Occupational and Environmental Medicine, 47(3), pp.199-211.

Shannon M., Xie Y., Verhaegen S., Wilson J., Berntsen H. F., Zimmer K. E., Ropstad E., Green B., and Connolly L. (2019). Data from: A Human Relevant Defined Mixture of Persistent Organic Pollutants (POPs) Affects In Vitro Secretion of Glucagon-Like Peptide 1 (GLP 1), but Does not Affect Translocation of its Receptor. Dryad Digital Repository. doi:10.5061/dryad.45sk03p 
Silvestroni, L., Fiorini, R. and Palleschi, S. (1997). Partition of the organochlorine insecticide lindane into the human sperm surface induces membrane depolarization and Ca2+ influx. Biochemical Journal, 321(3), pp.691-698.

Simpson A.K., Ward P.S., Wong K.Y., Collord G.J., Habib A.M., Reimann F., Gribble F.M. (2007). Cyclic AMP triggers glucagon-like peptide-1 secretion from the GLUTag enteroendocrine cell line. Diabetologia 50: 2181-2189.

Steinert R. E. and Begliger C. (2011). Nutrient sensing in the gut: interactions between chemosensory cells, visceral afferents and the secretion of satiation peptides, Physiology and Behavior. Elsevier Inc., 105(1), 62-70.

Taylor K. W., Novak R. F., Anderson H. A., Birnbaum L. S., Blystone C., and Lind L. (2013) Evaluation of the Association between Persistent Organic Pollutants (POPs) and Diabetes in Epidemiological Studies: A National Toxicology Program Workshop Review, Environ Health Perspect. 774(7), pp. 774-783.

Vestergren R., Berger U., Glynn A., Cousins I.T. (2012). Dietary exposure to perfluoroalkyl acids for the Swedish population in 1999, 2005 and 2010. Environ. Int. 49, 120127.

Westerink, R. (2013). Modulation of cell viability, oxidative stress, calcium homeostasis, and voltage- and ligand-gated ion channels as common mechanisms of action of (mixtures of) non-dioxin-like polychlorinated biphenyls and polybrominated diphenyl ethers. Environmental Science and Pollution Research, 21(10), pp.6373-6383.

Wilson J., Friis H., Elisabeth K., Frizzell C., Verhaegen S., Ropstad E., and Connolly L. (2016). Effects of defined mixtures of persistent organic pollutants (POPs) on multiple 
cellular responses in the human hepatocarcinoma cell line, HepG2, using high content analysis screening. Toxicology and Applied Pharmacology 294, 21-31.

Zhang L., Ren X.M., Wan B., and Guo L.H. (2014). Structure-dependent binding and activation of perfluorinated compounds on human peroxisome proliferator-activated receptor $\gamma$. Toxicology and Applied Pharmacology 279(3), 275-283.

TABLE 1. Overview of the 29 different POPs constituting the Total mixture for in vitro evaluation. For a complete description of selection of compounds and their individual concentration, see Berntsen et al., 2017.

\begin{tabular}{clll}
\hline \multicolumn{2}{c}{ Chlorinated } & Brominated & Perfluorinated \\
\hline PCB & \multicolumn{1}{c}{ OCP } & BFR & PFAAs \\
PCB 28 & p,p'-DDE & PBDE 47 & PFHxS \\
PCB 52 & HCB & PBDE 99 & PFOS \\
PCB 101 & $\alpha$-Chlordane & PBDE 100 & PFOA \\
& & & \\
PCB 118 & Oxychlordane & PBDE 153 & PFNA \\
PCB 138 & trans-Nonachlor & PBDE 154 & PFDA \\
PCB 153 & $\alpha$-HCH & PBDE 209 & PFUnDA \\
PCB 180 & $\beta$-HCH & HBCD & \\
& $\gamma$-HCH & & \\
& (Lindane) & & \\
& Dieldrin & & \\
\hline
\end{tabular}


TABLE 2. The comparison of measured GLP-1 peptide levels induced by co-mixtures to theoretical sum $\left(\sum=\right.$ Sum $)$ of corresponding sub-mixtures.

A. $3 \mathrm{~h}$ and $\mathrm{x} 500$ blood levels

Mixture
B. $24 \mathrm{~h}$ and $\mathrm{x} 50$ blood levels Mixture

\begin{tabular}{|c|c|c|c|c|c|c|c|}
\hline Mixture & Measured & & $\sum=S u m$ & Mixture & Meas & & $\sum=S u m$ \\
\hline & & $\mathrm{Cl}$ & 161.1 & & & $\mathrm{Cl}$ & 2357 \\
\hline & & $\mathrm{Br}$ & 55.1 & & & $\mathrm{Br}$ & 1774 \\
\hline & & PFAA & 168.3 & & & PFAA & 1977 \\
\hline Total & 572.6 & $>>$ & $\sum=384.5$ & Total & 3154 & $<<$ & $\sum=6108$ \\
\hline & & $\mathrm{Cl}$ & 161.1 & & & $\mathrm{Cl}$ & 2357 \\
\hline & & $\mathrm{Br}$ & 55.1 & & & $\mathrm{Br}$ & 1774 \\
\hline $\mathrm{Cl}+\mathrm{Br}$ & 105.3 & $<<$ & $\sum=216.2$ & $\mathrm{Cl}+\mathrm{Br}$ & 2577 & $<<$ & $\sum=4131$ \\
\hline & & $\mathrm{Br}$ & 55.1 & & & $\mathrm{Br}$ & 1774 \\
\hline & & PFAA & 168.3 & & & PFAA & 1977 \\
\hline $\mathrm{Br}+$ PFAA & 201.4 & $<<$ & $\sum=223.4$ & $\mathbf{B r}+$ PFAA & 1741 & $<<$ & $\sum=3751$ \\
\hline & & $\mathrm{Cl}$ & 161.1 & & & $\mathrm{Cl}$ & 2357 \\
\hline & & PFAA & 168.3 & & & PFAA & 1977 \\
\hline $\mathrm{Cl}+\mathrm{PFAA}$ & 250.8 & $<<$ & $\sum=329.4$ & $\mathrm{Cl}+$ PFAA & 2587 & $<<$ & $\sum=4334$ \\
\hline
\end{tabular}




\section{A $3 \mathrm{H}$}

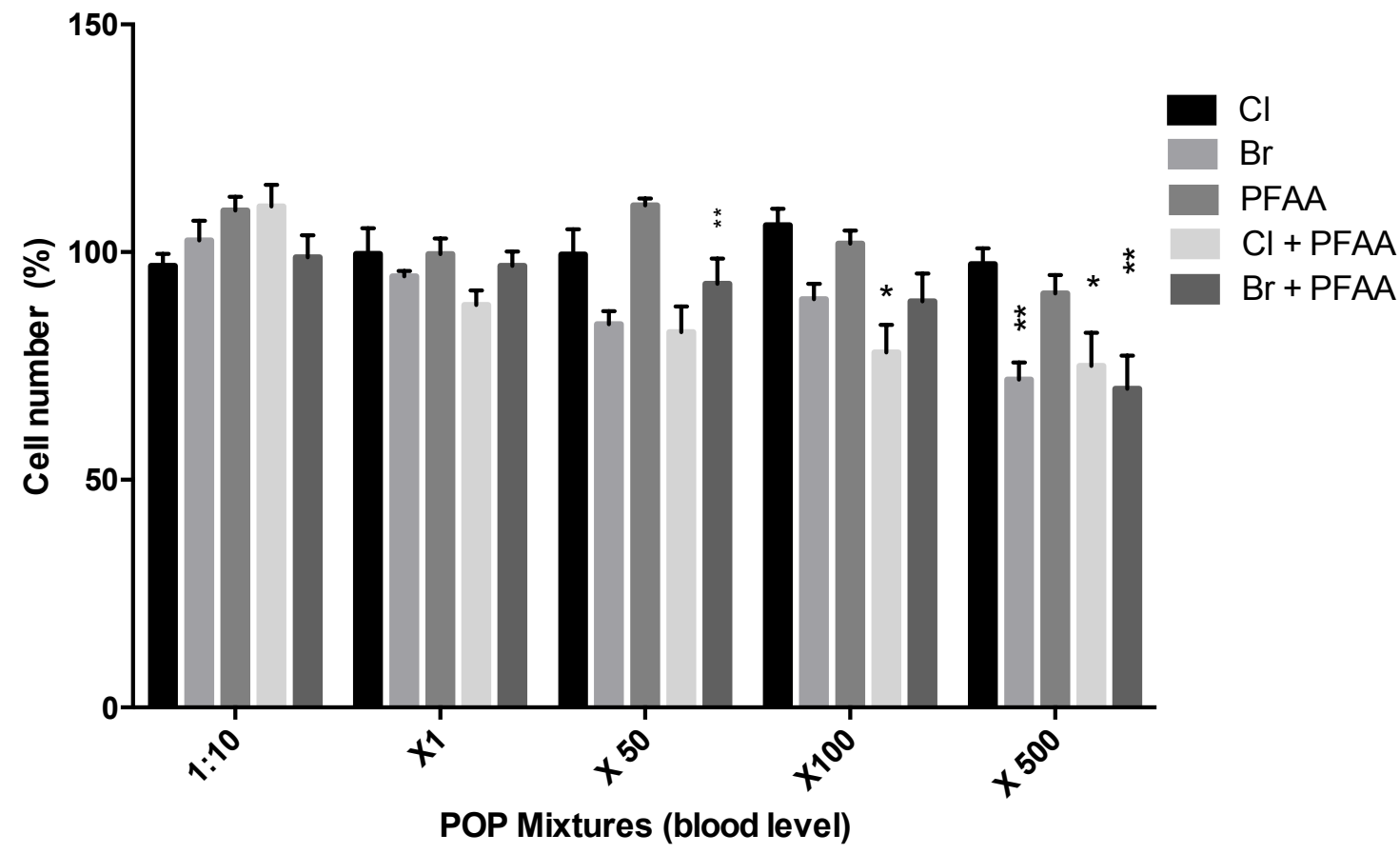

B 24H

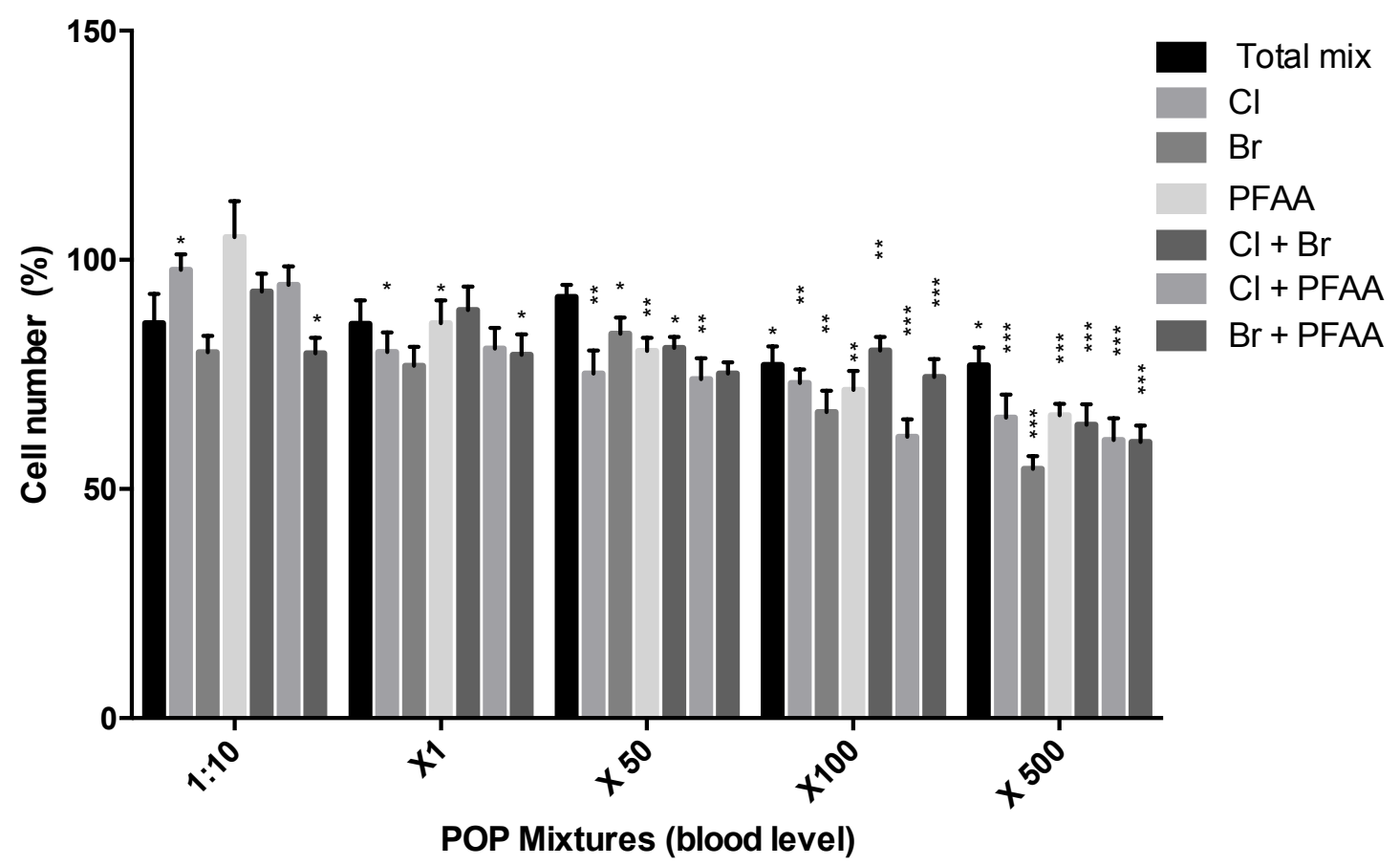

Fig. 1: Cell number changes in $p G I P / n e o$ STC-1 cells after a) 3h and b) 24 h exposure to POP mixtures. Cells were exposed to five concentrations of POPs (x 1:10, x 1, x 50, 100 and $x 500$ blood levels) and cytotoxicity was measured by cell number parameter. Data is expressed as a percentage of untreated

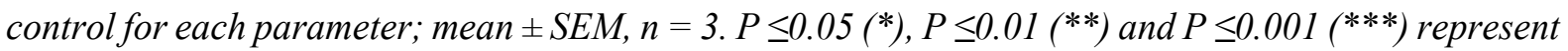
significant cytotoxic effects. 


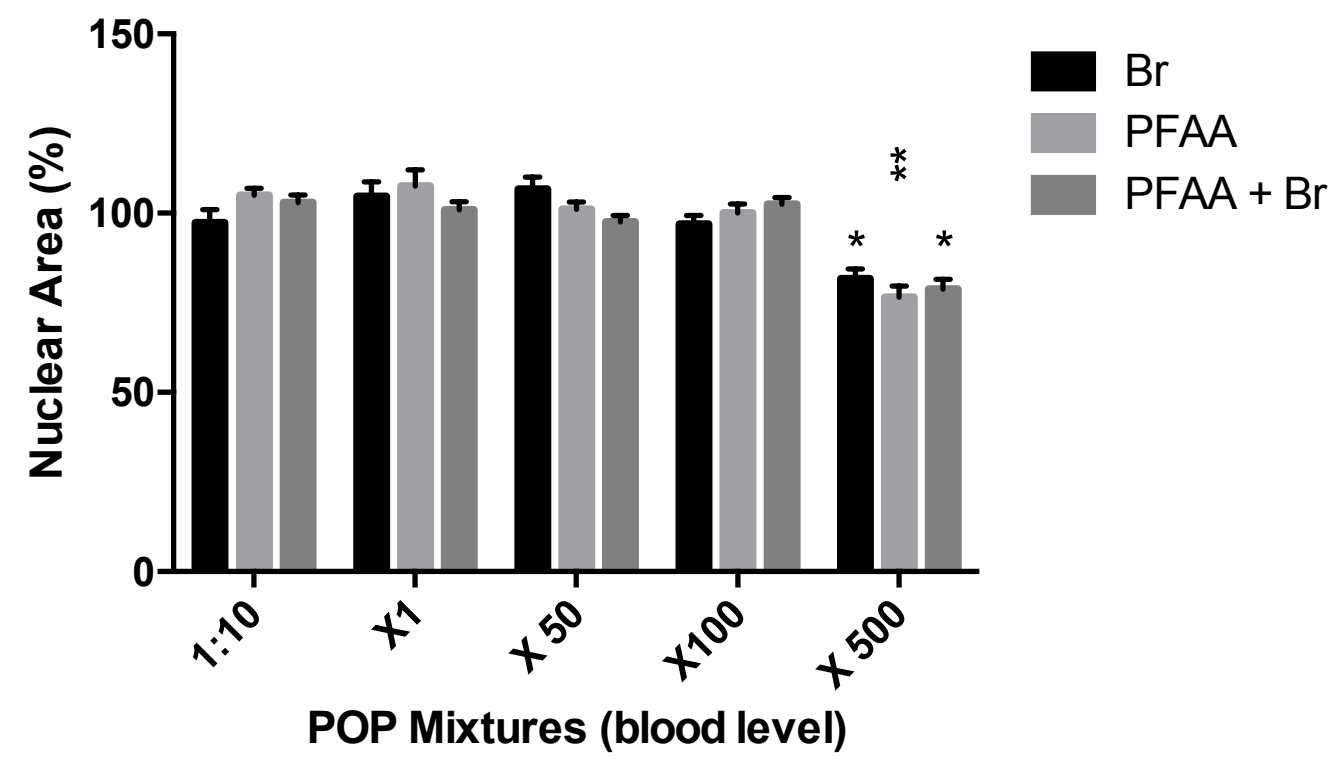

Fig. 2. Nuclear area changes in $p G I P / n e o$ STC-1 cells after exposure to POP mixtures. Cells were exposed to concentrations of POPS (1:10, X 1, X 50, X 100 and X 500 blood levels) for $24 \mathrm{~h}$ and cytotoxicity measured by nuclear area parameter. Data is expressed as a percentage of untreated control for each parameter; mean $\pm S E M, n=3 . P \leq 0.05$ (*), $P \leq 0.01$ (**) and $P$ $\leq 0.001(* * *)$ represent significant cytotoxic effects. 


\section{A $3 \mathrm{H}$}

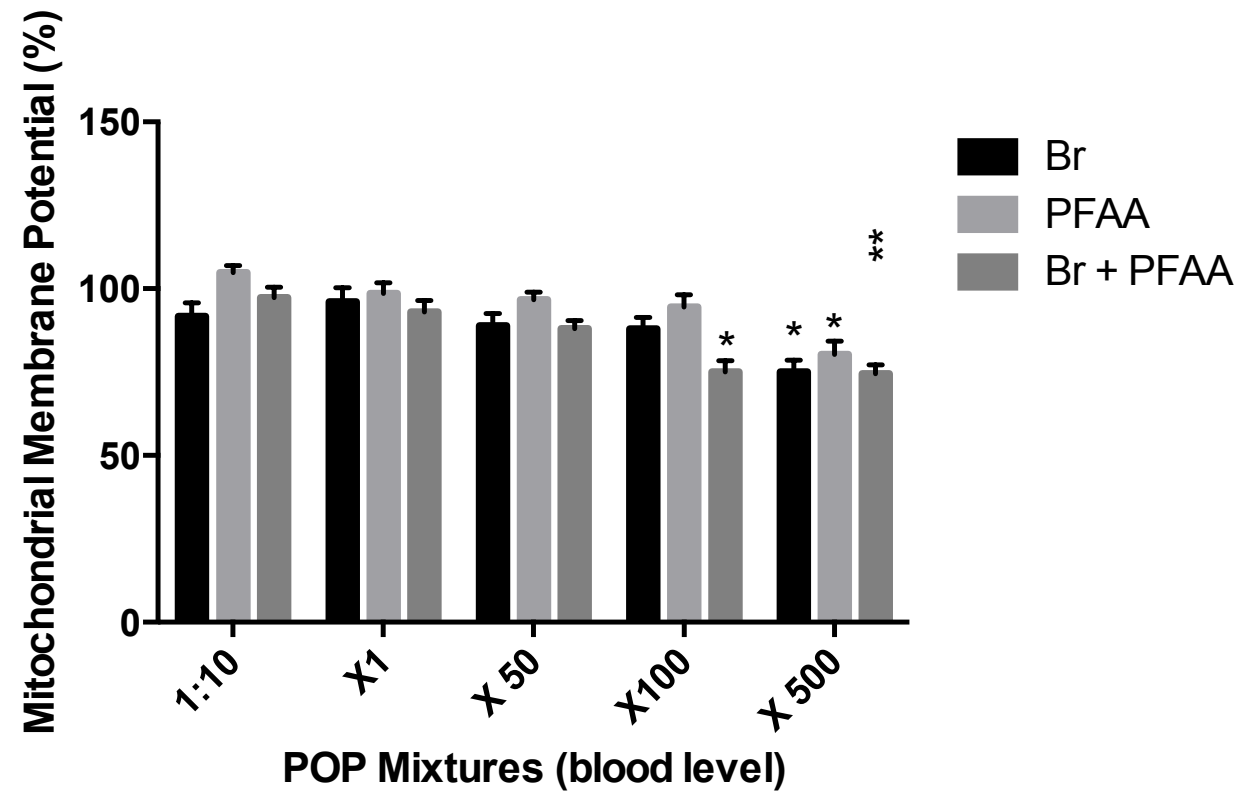

\section{B 24H}

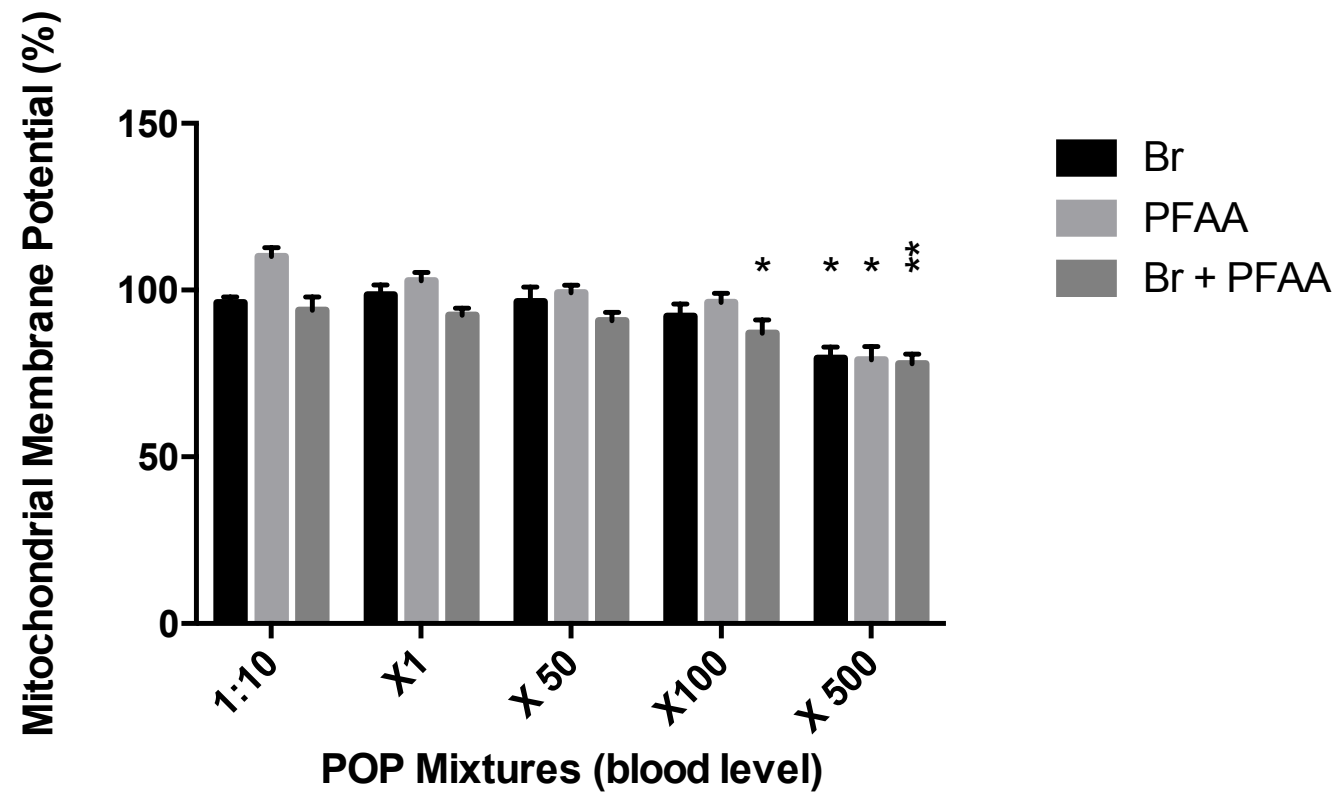

Fig. 3. Mitochondrial changes after exposure to three POP mixtures, $\mathrm{Br}, \mathrm{PFAA}$, and $\mathrm{Br}+$ PFAA, in pGIP/neo STC-1 cells. Cells were exposed to concentrations of POPs (1:10, X 1, X 50, X 100 and X 500 blood levels) for a) $3 h$ and b) $24 \mathrm{~h}$, cytotoxicity measured by the HCA endpoint mitochondrial membrane potential. Data is expressed as a percentage of untreated control for each parameter; mean $\pm S E M, n=3 . P \leq 0.05$ ( $\left.^{*}\right), P \leq 0.01$ (**) and $P \leq 0.001$ (***) represent significant cytotoxic effects. 

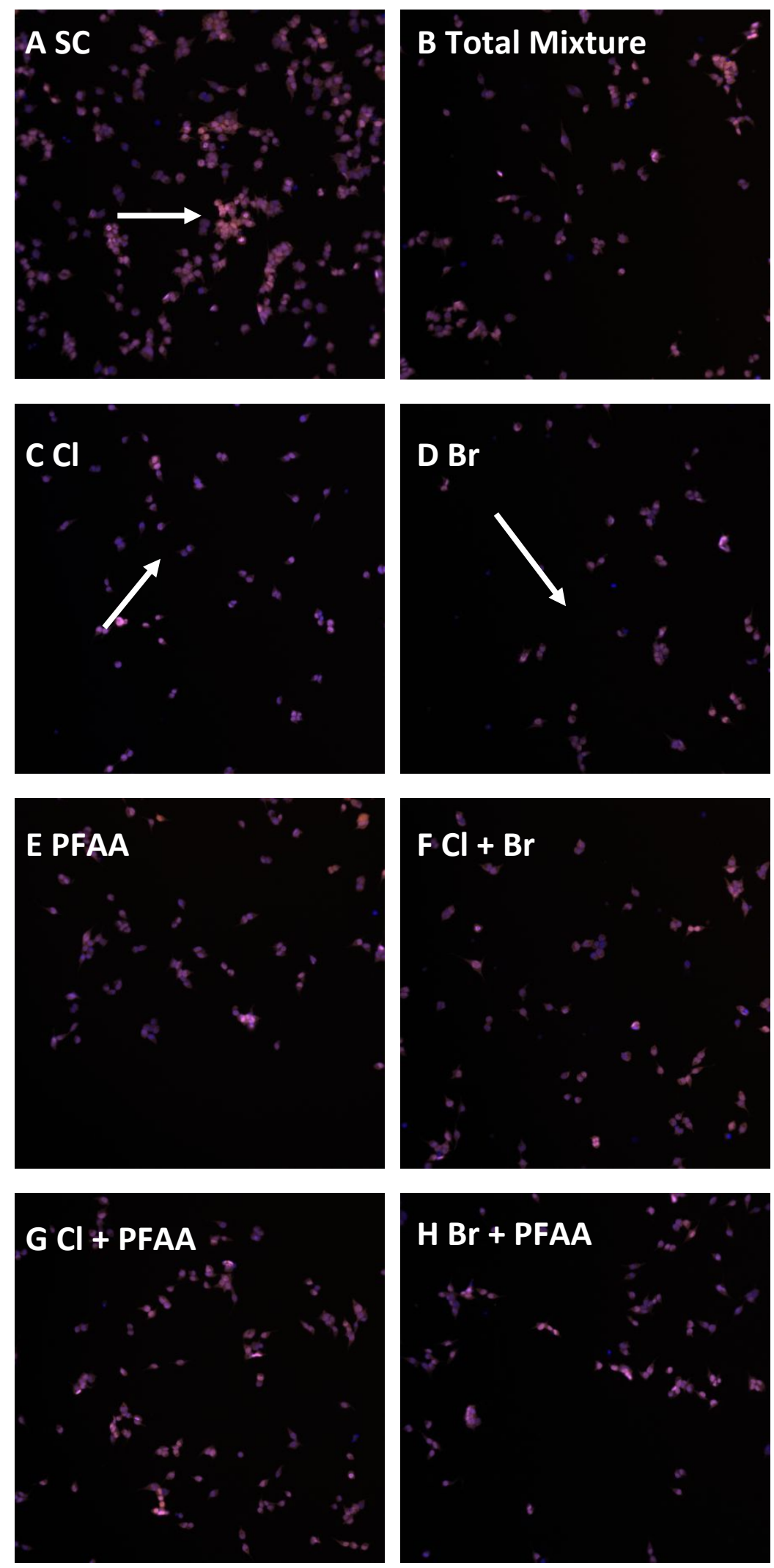

Fig. 4. HCA images for (A) negative control (DMSO) and B-H) POP mixtures after $24 \mathrm{~h}$ exposure. Each image was acquired at $20 \times$ objective magnification using Hoechst dye (blue; nuclear staining) and MMPD dye (pink; mitochondrial staining). The arrow in figure A shows a higher cell number and more intense stained mitochondria, arrows in figure $C$ and $D$ show decreased cell number and decreased MMPD dye intensity. 


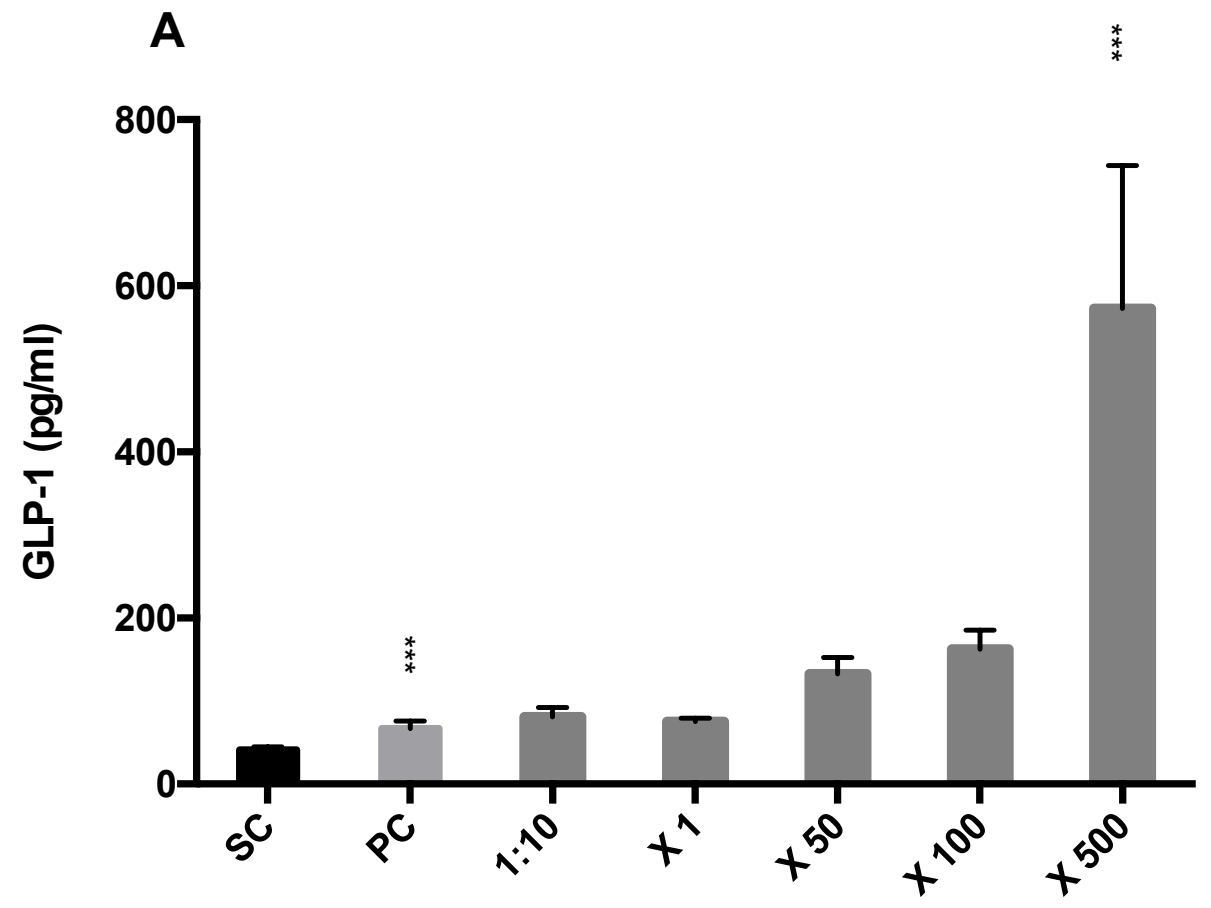

Total mixtures (blood level) 


\section{B}

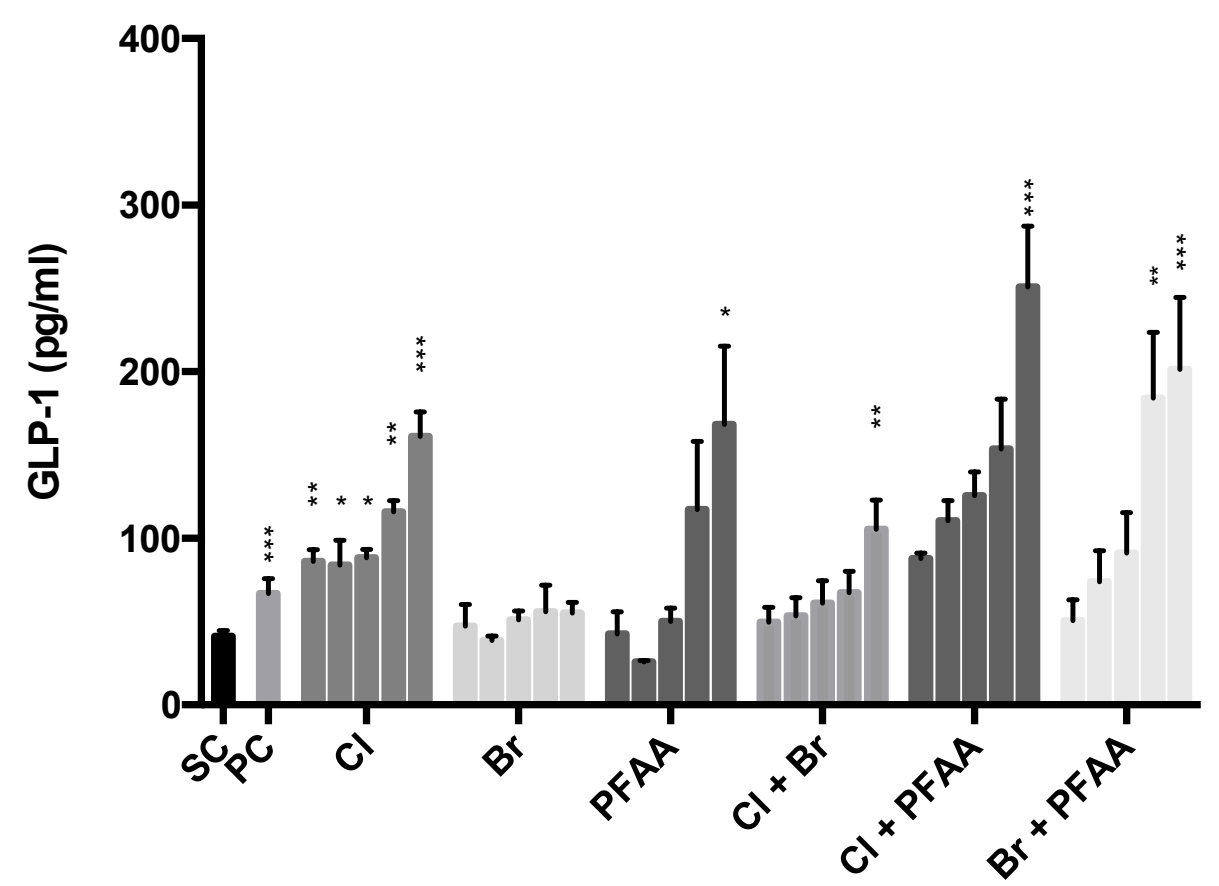

Fig 5. GLP-1 secretory responses of $p G I P / n e o$ : STC-1 cells during 3 h exposure to A) Total mixture; B) $\mathrm{Cl}, \mathrm{Br}, \mathrm{PFAA}, \mathrm{Cl}+\mathrm{Br}, \mathrm{Cl}+\mathrm{PFAA}$, and $\mathrm{Br}+\mathrm{PFAA}$ mixtures. Graph shows GLP-1 secretion from $p G I P / n e o: S T C-1$ cells (mean 'SEM, $n=3$ ) following 3 h incubation with solvent control, positive control, and each mixture at 1:10, X 1, X 50, X 100 and X 500 blood levels. $P \leq 0.05(*), P \leq 0.01$ $(* *), P 0.001 \leq\left(^{* * *}\right)$ represent significance. 


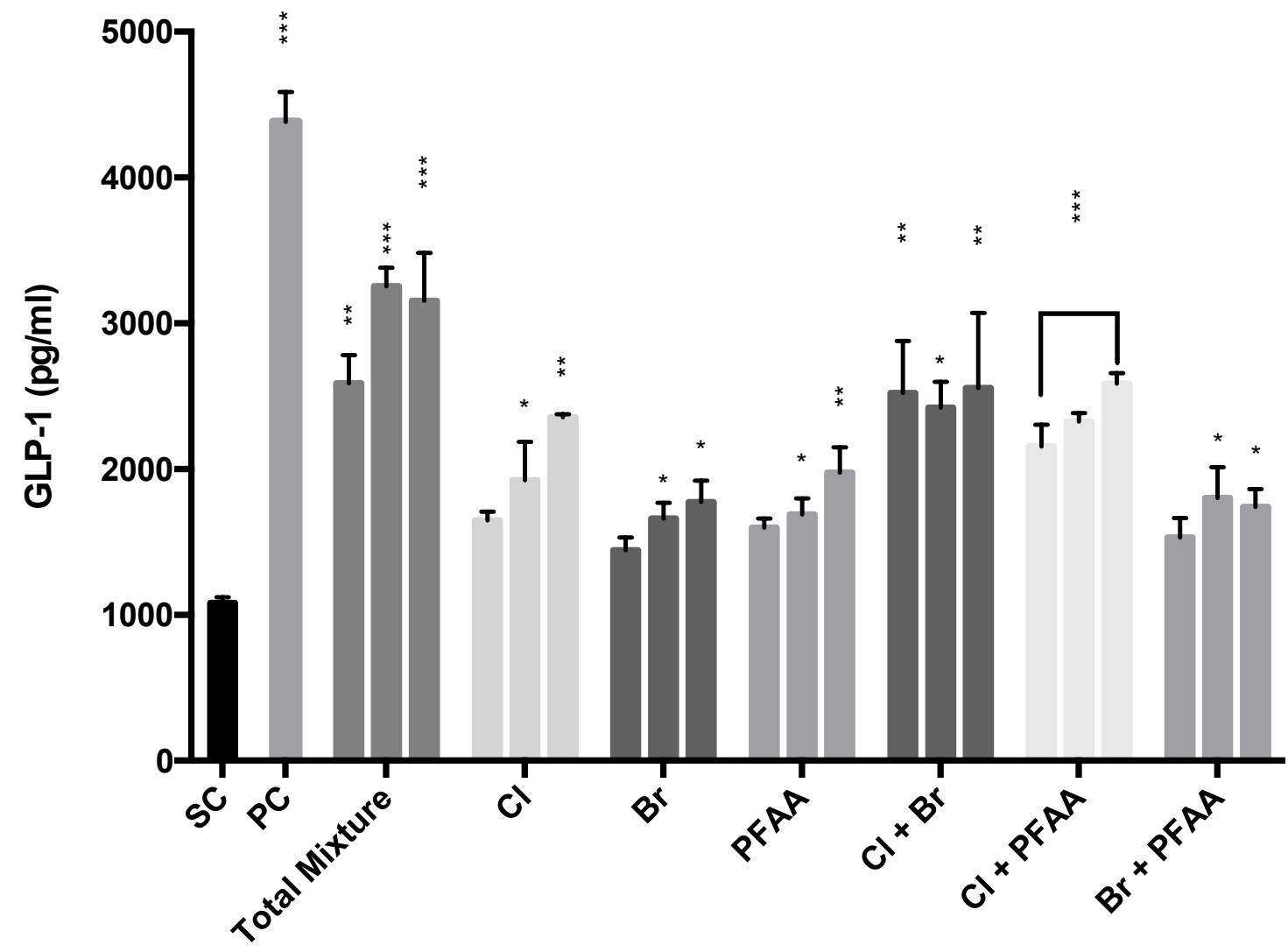

Fig. 6. GLP-1 secretory responses of $p G I P / n e o: S T C-1$ cells during 24 h exposure to Total mixture, $\mathrm{Cl}, \mathrm{Br}, \mathrm{PFAA}, \mathrm{Cl}+\mathrm{Br}, \mathrm{Cl}+\mathrm{PFAA}$, and $\mathrm{Br}+$ PFAA mixtures. Graph shows GLP-1 secretion from $p G I P / n e o: S T C-1$ cells (mean $\pm S E M, n=3$ ) following 3 h incubation with solvent control (SC), positive control $(P C)$, and (x 1:10, $x 1$, and $x 50$ blood levels). $P \leq 0.05\left(^{*}\right), P \leq 0.01$ (**), $P 0.001 \leq$ $(* * *)$ represent significance. 